\title{
Polymorphism of CYP1A1 (Ile462Val) Gene Related to Uterine Myoma in Malays Ethnicity of South Sumatera
}

\author{
Bella Ria Astuti ${ }^{1}$, Ferry Yusrizal ${ }^{1}$, Legiran ${ }^{1}$ \\ ${ }^{1}$ Biomedical Science Program, Faculty of Medicine, University of Sriwijaya. Negara Bukit Besar, Jl. Srijaya Negara, Bukit \\ Lama, Kec. Ilir Bar. I, Kota Palembang, Sumatera Selatan, Indonesia 30139
}

DATA OF ARTICLE:

Received: 17 Jun 2019

Reviewed: 27 Sep 2019

Revised: 03 Jan 2020

Accepted: 30 Jan 2020

*CORRESPONDENCE:

bellariaastuti@gmail.com

DOI:

10.18196/mm.200249

TYPE OF ARTICLE:

Research

\begin{abstract}
Myoma uteri related to the interaction between genes, hormones, growth factors, cytokines, and environment. Myomas are not found before menarche, whereas after menopause only $10 \%$ of myomas grow. The development of uterine myoma depends on estrogen. CYP1A1 is one of three members of the CYP1 family that is involved in the metabolism of a large number of xenobiotics. The purpose of this study was to analyze the relationship between the CYP1A1 gene polymorphism (Ile462Val) and the incidence of uterine myoma in ethnic Malays in South Sumatera. This research is an observational study with a case control design. The blood samples taken from 35 cases and 35 controls. The data was analyzed using the Chi-square test. The results indicate that there is a significant relationship between the use of contraceptives on the incidence of uterine myoma. There is a significant relationship between the CYP1A1 gene polymorphism (Ile462Val) and the CYP1A1 allele (Ile462 Val) with uterine myoma. It is concluded that there is a polymorphism relationship between the genotype and allele of the CYP1A1 gene (Ile462Val) and the incidence of uterine myoma in ethnic Malays in South Sumatera.
\end{abstract}

Keywords: Polimorphysme, Gen CYP1A1 (Ile462Val), Uterine Leiomyoma

\begin{abstract}
Abstrak: Mioma uteri adalah penyakit yang berkaitan dengan interaksi antara beberapa gen, hormon, faktor pertumbuhan, sitokin, dan lingkungan. Mioma tidak ditemukan sebelum terjadinya menarkhe, sedangkan setelah menopause hanya 10\% mioma yang tumbuh. Perkembangan mioma uteri bergantung pada estrogen. CYP1A1 merupakan satu dari tiga anggota famili CYP1 yang berperan serta pada metabolisme sejumlah besar xenobiotic. Tujuan penelitian ini untuk menganalisis hubungan antara polimorfisme gen CYP1A1 (Ile462Val) dengan kejadian mioma uteri pada etnis Melayu di Sumatera Selatan. Penelitian ini merupakan penelitian analitik observasional dengan desain case control. Sampel penelitian menggunakan sampel darah yang diambil pada 70 sampel yang terdiri dari 35 kasus dan 35 kontrol. Distribusi frekuensi hubungan polimorfisme dan sosiodemografi pada mioma uteri antara kasus dan kontrol dianalisis menggunakan uji Chisquare. Hasil penelitian ini menunjukkan bahwa ada hubungan yang bermakna pemakaian alat kontrasepsi terhadap kejadian mioma uteri, ada hubungan bermakna antara polimorfisme gen CYP1A1 (Ile462Val) dan alel CYP1A1 (Ile462Val) dengan mioma uteri. Disimpulkan bahwa terdapat hubungan polimorfisme antara genotipe maupun alel gen CYP1A1 (Ile462Val) dengan kejadian Mioma uteri pada etnis Melayu di Sumatera Selatan.
\end{abstract}

Kata Kunci: Mioma uteri, Polimorfisme, Gen CYP1A1, alel CYP1A1, Etnis Melayu

\section{INTRODUCTION}

Uterine myomas are benign tumors in the uterine muscle or myometrium that interact with several genes, hormones, growth factors, cytokines, and the environment. ${ }^{1}$ Myoma incidence is estimated at $20 \%-40 \%$ in the world. This disease does not occur before menarche, and after menopause it is estimated that $10 \%$ of this disease is still growing. ${ }^{2}$ The disease is predicted to reach 20- 
$30 \%$ in women over 35 years. In Indonesia, the incidence of uterine myomas is happened to $20-30 \%$ women over 35 years. ${ }^{3}$ Uterine myomas are often asymptomatic, but can cause abdominal discomfort, uterine bleeding, pelvic pain, and infertility. ${ }^{4}$ These tumors affect $30 \%$ of women of reproductive age. ${ }^{5}$ Uterine myomas as common benign neoplasms of the uterus involve nearly 30$40 \%$ of women childbearing age. ${ }^{6}$

Myoma uteri originates from the smooth muscle of the uterus and develops from stimulation of the hormone estrogen. The development of uterine myomas depends on estrogen. ${ }^{4}$ The number of estrogen receptors in the myoma tissue is above when compared to the muscle tissue in the surrounding uterus so that this disease grows very rapidly in pregnancy or enlarges at reproductive age and decreases in size after menopause or post menopause.?

The results show that the growth and development of uterine myomas is depended on estrogen. ${ }^{8}$ During pregnancy, uterine myomas can cause a number of problems such as bleeding in the first trimester, placental displacement, preterm labor, and miscarriage. ${ }^{9}$ Uterine myomas are a big problem, but effective therapy has not been obtained, because there is little information about the etiology of myoma itself. This disease does not often cause mortality, but morbidity that can result in abdominal pain, abnormal bleeding, and possibly infertility. ${ }^{10}$

The cause of uterine myoma is not known certainly, but the effects of hormonal, genetic, and growth factors on myoma growth are known. Several theories about meioma uteri are related to the decrease of fertility. The relationship between myoma and low fertility has been reported by two observational surveys. ${ }^{11}$ It has been shown that 27 $40 \%$ of those infected with this disease are infertile. The formation of these tumors comes from somatic changes in the muscle tissue cells of the uterus. Somatic changes are prone to partial and complete chromosomal mutations. Chromosomal aberrations can be found in $23-50 \%$ of the results of this disease examination and the overall result $(36.6 \%)$ is found on chromosome 7 ( $\operatorname{del}(7)$ (q 21) / q 21 q 32$).{ }^{12}$

Muscle cells contribute to uterine myoma. There are two estrogen receptors in uterine myomas, namely ER-alpha and ER-beta. ${ }^{13}$ The CYP450 cytochrome system is a group of enzymes involved in the biosynthesis of steroid hormones and the activation of metabolic carcinogens. CYPIA1 is a CYP450 enzyme, the main enzyme involved in the catabolism of estrogen. CYP1A1 is one of three members of the CYP1 family that is involved in the metabolism of a large number of xenobiotics.

The polymorphism of the CYP1A1 gene can be found by analyzing PCR-RFLP (Polymerase Chain Reaction Restriction Fragment Length Polymorphism), so the change in location of $\mathrm{G}$ to $\mathrm{T}$ is known. Ye et al. (2018) ${ }^{1}$ proved that there is a risk relationship between uterine leiomyoma and CYP1A1 gene polymorphism, this is the same as the study results obtained by Herr, et al (2006). ${ }^{6}$ who stated that the polymorphism of the cytochrome P450 1A1 gene in uterine leiomyomas has nothing to do with the polymorphism of the CYP1A1 gene. Based on the previous research, it is known that there is a relationship between GEN CYP1A1 (Ile462 Val) and leiomyoma uteri, therefore it is necessary to study the relationship between CYP1A1 gene polymorphism (Ile462 Val) and uterine myoma in Malays ethnicity in Indonesia, especially in South Sumatera, which is Indonesia's occupied territory. the majority ethnic Malay descent.

\section{MATERIALS AND METHOD}

This analytic observational study used a case control design. This analytical study explored risk factors that are studied with a retrospective approach. This study was approved by the ethics committee of the Medical Faculty of Sriwijaya University and all respondents had signed an informed consent.

Patients who seek treatment at the Obstetrics and Gynecology polyclinic RS. Dr. Mohammad Hoesin in Palembang and diagnosed with uterine myoma was the population of this analytic study. Samples were taken of 35 cases and 35 controls who met the inclusion and exclusion criteria. The inclusion criteria for the case group were classified as Malay ethnicity women diagnosed with uterine myoma as evidenced by ultrasound examination and had the results of an anatomical pathology examination, while in the control group, Malay ethnic women who were not diagnosed with this disease could be proven by ultrasound. The case and control groups were willing to have blood drawn, signed an informed consent and were 16 to 50 years old, while the exclusion criteria were women with gynecological neoplasm.

Sample, in the form of $3 \mathrm{ml}$ of blood from patients and healthy volunteers, were collected in a tube containing EDTA as an anticoagulant. Blood from each respondent in this study was stored at $20^{\circ} \mathrm{C}$ until DNA extraction was performed. DNA extraction using a DNA extraction kit (Promega). 
The genotype of the CYP1A1 gene (Ile462Val) was determined by the Polymerase Chain Reaction Restriction Fragmenth Length Polymorphism (PCRRFLP) method, using forward primer: 5'CTGTCTCCCTCTGGTTACAGGAAGC-3 'and reverse primer: 5'-TTCCACCCGTTGCAGCAGGATAGCC-3'

The Polymerase Chain Reaction process was carried out in the I - cycler (Biorad) machine. Basically, DNA amplification using the Polymerase Chain Reaction machine is a bireksional repetitive in vitro DNA synthesis through the extension of a pair of oligonucleotide primers that have been designed through the nucleotide sequences of the two amplified DNA chains.

The DNA synthesis process that has been carried out in 35 cycles runs in three stages of reactions that occur at different temperatures, namely the denaturation reaction at $94^{\circ} \mathrm{C}$ for 5 minutes, the annealing reaction at $64.7^{\circ} \mathrm{C}$ for 30 seconds, and the extension reaction at $72^{\circ} \mathrm{C}$ for 30 seconds. Before that, the pre-denaturation process was carried out for 5 minutes at a temperature of $94^{\circ} \mathrm{C}$. This denaturation reaction functions to separate the DNA double chain into a single DNA chain. In this annealing reaction, the two primers attach to the two single DNA chains. After that in the extension reaction, the additional extension lasted $72{ }^{\circ} \mathrm{C}$ for 10 minutes. Polymerase Chain Reaction products are electrophoresed on $2 \%$ agarose gel to produce ethidium bromide.

Analysis of the frequency distribution data of the relationship between polymorphism and sociodemographic on uterine myoma between cases and controls using the Chi-square test to determine the odds ratio (OR) with a confidence limit of $95 \%$ and $P=<0.05$ was considered statistically significant

\section{RESULT}

Sociodemographic characteristics both cases and controls are shown in Table 1. The results of this study indicate that uterine myoma was found more frequently in women over 35 years in the myoma uterine case group, as many as 25 respondents (71.4\%). Based on the Chi Square test, it shows that there is no significant relationship between the age of the respondent and the incidence of uterine myoma ( $\rho>0.05)$.

Besides, the respondents whose age of menarche less than 10 years in the case group were very few, namely 1 person (2.9\%) and none in the control group (0.0\%). Respondents whose menarche age $>10$ years in the case group were 34 people (97.1\%) and in the control group, 35 people (100\%). Based on the Chi Square test, there was no significant relationship between the age of menarche and the incidence of uterine myoma ( $\rho$ > 0.05).

There were 19 respondents (54.3\%) who gave birth less than 2 times in the case group and 15 (42.9\%) in the control group. Respondents who gave birth more than 2 times in the case group were 16 people (45.7\%) and in the control group were 20 people (57.1\%). Based on the Chi Square test, there was no significant relationship between the number of births and the incidence of uterine myoma ( $\rho>$ 0.05).

The number of respondents who did not use contraception in the case group was 26 people (74.3\%) and 12 people in the control group (34.3\%), while 23 respondents in the control group used contraception $(65,7 \%)$ and respondents who did not use contraception were 12 people (34.3\%). Based on the Chi Square test, it shows that there is a significant relationship between the use of contraceptives to the incidence of uterine myoma $(\rho<0.05)$.

In this study, the respondents with nonsmoking partners in the case group were 14 and in the control group 14 people (40.0\%), while respondents with smoking partners were 21 (60.0\%) and in the case group and in the control group. Based on the results of the Chi Square test, it showed that there was no significant relationship between partners who smoked and the incidence of uterine myoma ( $\rho>0.05)$.

In the family history data on the incidence of uterine myoma in the case group were 5 respondents (14.3\%) and the control group was 3 $(8.6 \%)$, while there was no family history of the incidence of uterine myoma in the case group as many as 30 respondents $(85,7 \%)$ and the control group was 32 (91.4\%). Based on the results of the Chi Square test, it was found that there was no significant relationship between family history and the incidence of uterine myoma ( $p>0.05)$.

The measurements of the genetic frequency of respondents with uterine myomas with wild type (TT) characteristics, heterozygous mutants (TC) and homozygous mutants (CC) are shown in Table 2 . In the case group, uterine myomas with wild type characteristics were the most with 22 people (62.9\%), followed by heterozygous mutants (TC) by 11 people (31.4\%) and homozygous mutants by 2 people (5.7\%). In the control group, uterine myoma with wild type characteristics was the most with 12 people (34.2\%), followed by heterozygous mutants (TC) by 15 people (42.9\%) and homozygous mutants as many as 8 people (22.9\%). 
Table 1. Frequency Distribution and the Relationship of the Characteristics of Research Subjects to the Incidence of Uterine Myoma

\begin{tabular}{|c|c|c|c|c|c|c|c|}
\hline \multirow[b]{2}{*}{ Characteristics } & \multicolumn{4}{|c|}{ Uterin Myoma } & \multicolumn{3}{|c|}{ Total } \\
\hline & $\begin{array}{c}\text { Case } \\
(n=35)\end{array}$ & $\%$ & $\begin{array}{l}\text { Control } \\
(n=35)\end{array}$ & $\%$ & n (\%) & $\mathbf{P}$ & OR $(95 \% \mathrm{CI})$ \\
\hline \multicolumn{8}{|l|}{ Age } \\
\hline$<35$ years & 10 & 28.6 & 18 & 51.4 & $28(40.0)$ & 0,088 & $2.647(0985-7.113)$ \\
\hline $\begin{array}{l}>35 \text { years } \\
\text { Menarche }\end{array}$ & 25 & 71.4 & 17 & 48.6 & $42(60.0)$ & & \\
\hline$<10$ years & 1 & 2.9 & 0 & 0 & $1(1.4)$ & 1,000 & $2.029(1.597-2.578)$ \\
\hline$>10$ years & 34 & 97.1 & 35 & 100 & $69(98.6)$ & & \\
\hline \multicolumn{8}{|l|}{ Parity } \\
\hline$<2$ & 19 & $54 \cdot 3$ & 15 & 42.9 & $34(48.6)$ & 0,473 & $0.632(0.246-1.623)$ \\
\hline$>2$ & 16 & $45 \cdot 7$ & 20 & 57.1 & $36(51.4)$ & & \\
\hline \multicolumn{8}{|l|}{ Contraception } \\
\hline No & 26 & 74.3 & 12 & $34 \cdot 3$ & $38(54.3)$ & $0,002 *$ & $0.181(0.064-0.506)$ \\
\hline Yes & 9 & 25.7 & 23 & 65.7 & $32(45.7)$ & & \\
\hline \multicolumn{8}{|l|}{ Smoking } \\
\hline No & 14 & 40.0 & 14 & 40.0 & $28(40.0)$ & 1,000 & $1.000(0.384-2.602)$ \\
\hline Yes & 21 & 60.0 & 21 & 60.0 & $42(60.0)$ & & \\
\hline \multicolumn{8}{|l|}{ Family History } \\
\hline No & 30 & 85.7 & 32 & 91.4 & $62(88.6)$ & 0,707 & $1.778(0.391-8.092)$ \\
\hline Yes & 5 & $14 \cdot 3$ & 3 & 8.6 & $8(11.4)$ & & \\
\hline
\end{tabular}

Note:*) based on $\chi_{2}$ Chi-Square test there is significant relation $(\mathrm{p}<0,05)$

Table 2. Frequency distribution of the CYP1A1 (lle462Val) genotype on the incidence of uterine myoma

\begin{tabular}{lccccc}
\hline & \multicolumn{3}{c}{ Uterin Myoma } & \multicolumn{2}{c}{ Total } \\
\cline { 2 - 6 } Characteristics & $\begin{array}{c}\text { Case } \\
(\mathbf{n}=35)\end{array}$ & $\%$ & $\begin{array}{l}\text { Control } \\
(\mathbf{n}=35)\end{array}$ & $\%$ & $\mathbf{n}(\%)$ \\
\hline TT (Wild Type) & 22 & 62.9 & 12 & 34.2 & $\begin{array}{l}34 \\
(48.6)\end{array}$ \\
TC (Mutant & 11 & 31.4 & 15 & 42.9 & $\begin{array}{l}26 \\
(37.1)\end{array}$ \\
$\begin{array}{l}\text { Heterozygous) } \\
\text { CC (Mutant } \\
\text { Homozygous) }\end{array}$ & 2 & 5.7 & 8 & 22.9 & $\begin{array}{l}10 \\
(14.3)\end{array}$ \\
Total & 35 & 100 & 35 & 100 & $\begin{array}{l}70 \\
(100)\end{array}$ \\
\hline
\end{tabular}

Note: *) based on $\chi 2$ test

Table 3 Frequency distribution of the CYP1A1 lle462Val gene allele in cases and controls of uterine myoma

\begin{tabular}{|c|c|c|c|c|c|}
\hline \multirow{2}{*}{ Allel } & \multicolumn{4}{|c|}{ Uterin Myoma } & \multirow{2}{*}{$\begin{array}{l}\text { Total } \\
\mathrm{n}(\%)\end{array}$} \\
\hline & Case & $\%$ & Control & $\%$ & \\
\hline C & 15 & 21.4 & 31 & 44.3 & $46(32.9)$ \\
\hline $\mathrm{T}$ & 55 & 78.6 & 39 & 55.7 & $94(67.1)$ \\
\hline Total & 70 & $0 \%$ & 70 & $0 \%$ & $140(100)$ \\
\hline
\end{tabular}

Table 4. Analysis of the Relationship between CYP1A1 Genotype Polymorphisms (Ile462Val) and the incidence of uterine myoma.

\begin{tabular}{|c|c|c|c|c|c|c|c|}
\hline \multirow{2}{*}{$\begin{array}{l}\text { Geno } \\
\text { type }\end{array}$} & \multicolumn{4}{|c|}{ Uterin Myoma } & \multicolumn{3}{|c|}{ Total } \\
\hline & Cs & $\%$ & CtI & $\%$ & $\mathbf{P}$ & OR & $95 \% \mathrm{Cl}$ \\
\hline $\mathrm{TT}$ & 22 & 62.90 & 12 & 34.20 & $\begin{array}{l}0.028 \\
*\end{array}$ & $\begin{array}{l}7.3 \\
33\end{array}$ & $\begin{array}{l}\left(1.337^{-}\right. \\
40.209)\end{array}$ \\
\hline TC & 11 & 31.40 & 15 & 42.9 & & & \\
\hline CC & 2 & 5.70 & 8 & 22.90 & & & \\
\hline Total & 35 & 100 & 35 & 100 & & & \\
\hline
\end{tabular}

The measurement of the allele frequency distribution, based on Table 3. T allele in the case group amounted to 55 (78.6\%) and 39 controls (5.7\%), the $C$ allele in the case group amounted to 15 (21.4\%) and control 31 (44.3\%).

Based on the Table 4, the analysis of the relationship between the $\mathrm{CYP}_{1} \mathrm{~A} 1$ gene polymorphism (lle462 Val) and the incidence of uterine myoma showed that the TT genotype in the case group was 22 (62.9\%) and 12 in control (34.3\%), while the TC genotype in the case group amounted to 11 (31.4\%) and control amounted to 15 (42.9\%). Genotype CC in case group 2 people (5.7\%) and control 8 (22.9\%). The highest number was found in the TT genotype in the group of cases of uterine myoma. Based on the results of statistical analysis using the Chi-Square test, it was found that there was a significant relationship between the CYP1A1 gene polymorphism (Ile462 Val) and uterine myoma $(p<0.05)$.

Table 5. Analysis of the Correlation of $\mathrm{CYP}_{1} \mathrm{~A} 1$ (lle462Val) allele polymorphisms to the incidence of uterine myoma.

\begin{tabular}{|c|c|c|c|c|c|c|c|}
\hline \multirow{2}{*}{$\begin{array}{l}\text { Geno } \\
\text { type }\end{array}$} & \multicolumn{4}{|c|}{ Uterin Myoma } & \multirow[b]{2}{*}{$\mathbf{P}$} & \multirow[b]{2}{*}{ OR } & \multirow[b]{2}{*}{$\begin{array}{c}95 \% \\
\mathrm{Cl}\end{array}$} \\
\hline & Cs & $\%$ & Ctl & $\%$ & & & \\
\hline $\mathrm{T}$ & 55 & $\begin{array}{l}78 . \\
6\end{array}$ & 39 & 55.7 & $0.007^{*}$ & $\begin{array}{l}0.34 \\
3\end{array}$ & $\begin{array}{l}(0.164 \\
- \\
0.720)\end{array}$ \\
\hline Total & 15 & $\begin{array}{l}21 . \\
4 \\
100\end{array}$ & 31 & $\begin{array}{l}44.3 \\
100\end{array}$ & & & \\
\hline
\end{tabular}


The analysis of the relationship between the polymorphism of the CYP1A1 gene allele (Ile462Val) on the incidence of uterine myoma found that the $T$ allele in the case group was 55 (78.6\%) and the control was $39(55.7 \%)$, while the $C$ allele in the case group amounted to 15 (21.4\%) and control amounted to 31 (44.3\%). A higher number was found in the $\mathrm{T}$ allele in the case of uterine myoma than the $C$ allele as well as in the control group. The results of statistical analysis using the Chi-Square test to see the relationship between the CYP1A1 allele (lle462 Val) and the incidence of uterine myoma showed a significant relationship between the CYP1A1 allele (lle462 Val) on the incidence of uterine myoma with a value of $\rho=0.007$ (OR 0.343; $95 \% \mathrm{Cl} 0.164-0.720)$.

\section{DISCUSSION}

CYP1A 1 is one of three members of the CYP1 family that is involved in the metabolism of a large number of xenobiotics. CYP1A1 is one of the major cytochromes $\mathrm{P} 450$ enzymes, examined extensively for its ability to activate compounds that are carcinogenic. CYP1A1 gene polymorphisms, contribute to an increase in the predisposition that causes uterine myoma. CYP1A1 is one of the CYP450 enzymes involved in the catabolism of estrogen.

Myoma uteri can be found more in the population of women aged over 35 years in the myoma uterine case group. This is in accordance with the results of Ye et al (2008), ${ }^{1}$ who states that women over 35 years have a high risk in experiencing uterine myoma. Likewise, with the results of research conducted by Octaviana and Pranajaya (2014) ${ }^{14}$ stated that the older a person is, the risk of developing myoma uteri increases.

Uterine myoma more often occurs at the above 10 years in the myoma uterine case group. The results of this study are supported by research which shows that menarche over 10 years of age have a risk of uterine myoma. The age of menarche varies from person to person, especially the age of menarche which is influenced by genetic and external factors, such as stress, diet, chronic disease, and lifestyle.

More uterine myomas were found at parity $<2$ in the uterine myoma case group. Nullipara, this incident is easier to find because the secretion of estrogen in pregnant women is completely different from the secretion by the ovaries in nonpregnant women. In pregnant women, almost all of the estrogen produced is estriol. Estriol is an estrogen which is relatively weaker than the estradiol secreted against the ovaries.
Uterine myomas are more common in women who do not use contraception. The results of this study are not in accordance with the research of Fahrunniza (2014) ${ }^{15}$ who stated that one of the triggers for uterine myoma is the use of the hormones estrogen and progesterone obtained through hormonal contraceptives.

The results of this study indicate that the respondents whose husbands smoke showed no relationship with cases of uterine myoma. This is in accordance with the results of research conducted by Wise (2016) ${ }^{16}$ who stated that there is no change in the risk of African and American women smoking. Although in theory, smoking can increase myoma risk because it can reduce estrogen levels in the body which results in the growth of uterine myomas.

The results showed that there was no significant relationship between family history and the incidence of uterine myoma. The results of this study are not in accordance with the research of Nida (2014) ${ }^{15}$ who states that there is a link between family history and the incidence of uterine myoma. According to the theory, women who have a hereditary history of uterine myoma are 2.5 times more likely to experience myoma than women without this lineage.

The identification of the CYP1A1 (lle462Val) gene polymorphism in this uterine myoma patient is in accordance with a study conducted by Hsieh (2004) which showed that there were genotypes between wild type, heterozygous and homozygous mutants in samples of Chinese women. Polymorphism of the CYP1A1 gene (lle462Val) may be a risk factor for uterine myoma in Iranian women.

Genotype polymorphisms and the CYP1A1 gene allele (lle462Val) are associated with the incidence of uterine myoma against ethnic Malays in South Sumatera. The contribution of CYP1A1 in the development of uterine myoma varies between each population because it is influenced by many things including the presence of the hormone estrogen, and the interaction of genes with environmental factors.18 Polymorphisms in the CYP1A1 gene (lle462Val) are a risk factor for uterine myoma in Chinese, Iranian, German women due to any change in enzymatic activity.

\section{CONCLUSION}

There is a polymorphism relationship between the genotype and allele of the CYP1A1 gene (lle462Val) and the incidence of uterine myoma in ethnic Malays in South Sumatera. It is necessary to carry out further research on the 
polymorphism of the CYP1A1 gene (Ile462Val) against the incidence of uterine myoma that occurs in other populations in Indonesia, so that it can be compared to the function of the CYP1A1 gene polymorphism (Ile462 Val) on the incidence of uterine myoma and it is necessary to add incubation to the Restriction Fragment Length Polymorphism process.

\section{REFERENCES}

1. Ye Y, Cheng $X$, Luo HB, Liu L, Li YB, and Hou YP, CYP1A1 and CYP1B1 genetic polymorphisms and uterine leiomyoma risk in Chinese women. $J$ Assist Reprod Genet. 2008 Aug; 25(8): 389-394

2. Sparic R, Mirkovic L, Malvasi A, Tinelli A. Epidemiology of Uterine Myomas: A Review. Royan Institute International Journal of Fertility and Sterility. 9(4), Jan-Mar 2016: 424-435.

3. Kurniaty $R$, dan Sunarsih. Faktor-Faktor yang Berhubungan dengan Kejadian Mioma Uteri di RSUD Dr. H Abdul Moeloek Bandar Lampung Tahun 2016. Jurnal Kebidanan, 4(3), Juli 2018 : 100-105

4. Herr D, Bettendorf H, Denschlag $\quad D$, Keck C, Pietrowski D. Cytochrome $\mathrm{P}_{2} \mathrm{~A} 13$ and $\mathrm{P}_{1} \mathrm{~A} 1$ gene polymorphisms are associated with the occurrence of uterine leiomyoma. Arch Gynecol Obstet.2006. 274(6): p. 367-371

5. Nierth-Simpson EN, Martin MM, Chiang TC, Melnik LI, Rhodes LV, Muir SE, Burow ME, McLachlan JA: Human uterine smooth muscle and leiomyoma cells differ in their rapid 17betaestradiol signaling: implications for proliferation. Endocrinology 2009; 150: 2436-2445.

6. Salimi S, Sajadian M, Khodamian M, Yazdi A, Rezaee S, Mohammadpour-Gharehbagh A, Mokhtari $M$, and Yaghmaie $M$. Combination effect of cytochrome P450 1A1 gene polymorphisms on uterine leiomyoma: A casecontrol study. Bosn J Basic Med Sci. 2016 Aug; 16(3): 209-214.

7. Sparic R, Mirkovic L, Malvasi A, and Tinelli A, Epidemiology of Uterine Myomas: A Review. Int J Fertil Steril. 2016 Jan-Mar; 9(4): 424-435. doi: 10.22074/ijfs.2015.4599

8. Lethaby A. and Vollenhoven B. Fibroids (uterine myomatosis, leiomyomas). Clinical Evidence, 2011;01:814: p. 1-31.

9. Makinen N, Vahteristo P, Kampjarvi K, Arola J, Butzow R, and Aaltonen LA. MED12 Exon 2 Mutations in Histopathological Uterine Leiomyoma Variants. Eur J Hum Genet. 2013 Nov; 21(11): 1300-130321. doi: 10.1038/ejhg.2013.33
10. Purohit P. and Vigneswaran K. Fibroids and Infertility. Curr Obstet Gynecol Rep. 2016; 5: 8188.

11. Marshall LM, Goldman MB. A prospective study of reproductive contraceptive factors and oral Steril. 1998;70(3):432-439.

12. Kurniasari T. Karaketristik Mioma Uteri di RSUD Dr. Moewardi Surakarta Periode Januari 2009 Januari 2010. Surakarta. Fakultas Kedokteran Universitas Sebelas Maret, 2010.

13. Jakimiuk AJ, Bogusiewicz M, Tarkowski R, Dziduch P, Adamiak A, Wróbel A, et al. Estrogen receptor alpha and beta expression in uterine leiomyomas from premenopausal women. Fertil Steril. 2004 Oct; 82 Suppl 3:1244-9. PMID: 15474102.

14. Octaviana A. dan Pranajaya R. Usia dan Paritas dengan Kejadian Mioma Uteri. Jurnal Ilimah Keperawatan Sai Betik. Okt, 2014. 10(2):209-214

15. Fahrunniza F, Astutik $\mathrm{H}$, dan Praptono $\mathrm{MGH}$. Kejadian Mioma Uteri pada Akseptor Hormonal. Jurnal Informasi Kesehatan Indonesia (JIKI),2015. 1(1):69-75

16. Wise LA, Laughlin-Tommaso SK. Epidemiology of Uterine Fibroids: From Menarche to Menopase. Clinical Obstetrics and Gynecology; 2016:59(1) : 224

17. Parker WH. Etiology, symptomatology, and diagnosis of uterine myomas. Fertil Steril. 2007 Apr;87(4):725-36. doi: 10.1016/j.fertnstert.2007.01.093

18. Hsieh YY, Chang CC, Tsai FJ, Lin CC, Yeh LS, and Peng CT. Androgen receptor trinucleotide polymorphism in leiomyoma. J Assist Reprod Genet. 2004;21:453-7. doi:10.1007/s108150048762-6. 